\title{
Isolation of high quality DNA: a protocol combining "rennet" and glass milk
}

\author{
Luiz Felipe Valter de Oliveira \\ Centro de Ciências Naturais e Exatas \\ Universidade Federal de Santa Maria \\ Santa Maria, RS, Brasil \\ Gabriel da Luz Wallau \\ PPG Biodiversidade Animal \\ Centro de Ciências Naturais e Exatas \\ Universidade Federal de Santa Maria \\ Santa Maria, RS, Brasil \\ Elgion Lucio Silva Loreto* \\ Departamento de Biologia \\ Universidade Federal de Santa Maria \\ CEP 97105-900, Santa Maria, RS, Brasil \\ E-mail: elgion.loreto@pq.cnpq.br
}

Financial support: This work was supported by grants from CNPq and Pró-Publicações Internacionais/PRPGP/UFSM.

Keywords: chymosin, DNA extraction, glass milk, rennet, rennin, silica.

High quality DNA is essential for many molecular biology techniques. However, the reagents used for that purpose usually are expensive and/or cause a high environmental impact. Here, we describe two alternative protocols that use inexpensive reagents and are not hazardous to the environment. The first protocol utilizes the enzyme chymosin, normally used as "rennet" in cheese production and which is easily obtained on the commercial market. The second protocol uses "rennet DNA extraction protocol" combined with the DNA binding capacity of glass powder (glass milk), which can easily be "home made". The first protocol is used when a high yield of DNA is needed, whereas the second protocol is used for production of a higher quality DNA, being able to work with sparse samples.

There are many protocols for DNA extraction and most use reagents, such as proteinase $\mathrm{K}$ or phenol, for DNA deproteinization (Chan et al. 2001; Niemi et al. 2001; Sato et al. 2001; Biase et al. 2002; Grachev et al. 2006). Reagents such as proteinase $\mathrm{K}$ normally come with an elevated cost or, such as phenol, are hazardous and require special discard procedures to minimize environmental impacts.

Here, we describe two protocols that can be used separately. However, the combination of both protocols is particularly useful to solve problems related to the quality of DNA extracted from some plants, since this is generally associated with secondary metabolites or latex. The first protocol uses the enzyme chymosin (rennin) present in "rennet", which is used in making cheese. This enzyme has proteolytic activities and is widely used for protein coagulation of milk in the production of cheese (Bansal et al. 2007; Choi et al. 2007; Sandra et al. 2007).

According to UniProt (2008), the chymosin enzyme (CYM - P00794/A8RRP5) is an aspartic endopeptidase that belongs to the peptidase A1 family. This protein presents three molecular functions: aspartyl protease, hydrolase and protease. Its function in the biological process is defined as a protein whereby nutrients are rendered soluble and capable of being absorbed by the organism or cell and the activity specific is defined as catalysis of the lysis of peptide bonds with broad specificity similar to that of pepsin A (Mohanty et al. 2003; Rampilli et al. 2005).

The second protocol is also based on the capacity of chymosin proteolysis, but now the obtained DNA is additionally purified through its ability of binding positive electrical charged silica particles, also known as "glass milk". The binding of DNA in the presence of chaotropic agents, such as $\mathrm{NaI}$ or $\mathrm{NaClO}_{4}$, to silica or glass particles is well known (Boom et al. 1990). Melzak et al. (1996) describes some features that control the absorption of DNA by silica particles such as: (i) weak electrostatic repulsion forces, (ii) dehydration, and (iii) hydrogen bond formation. Glass milk, having these well-known characteristics, has been used in other methodologies of purification and DNA capture (Haugland et al. 1999; Huijun et al. 2000; Backer et al. 2001; England et al. 2001; Haugland et al. 2002; Nakama and Morishita 2004; Rohland et al. 2004; Zhang et al. 2004; Ros-Chumillas et al. 2007).

*Corresponding author 

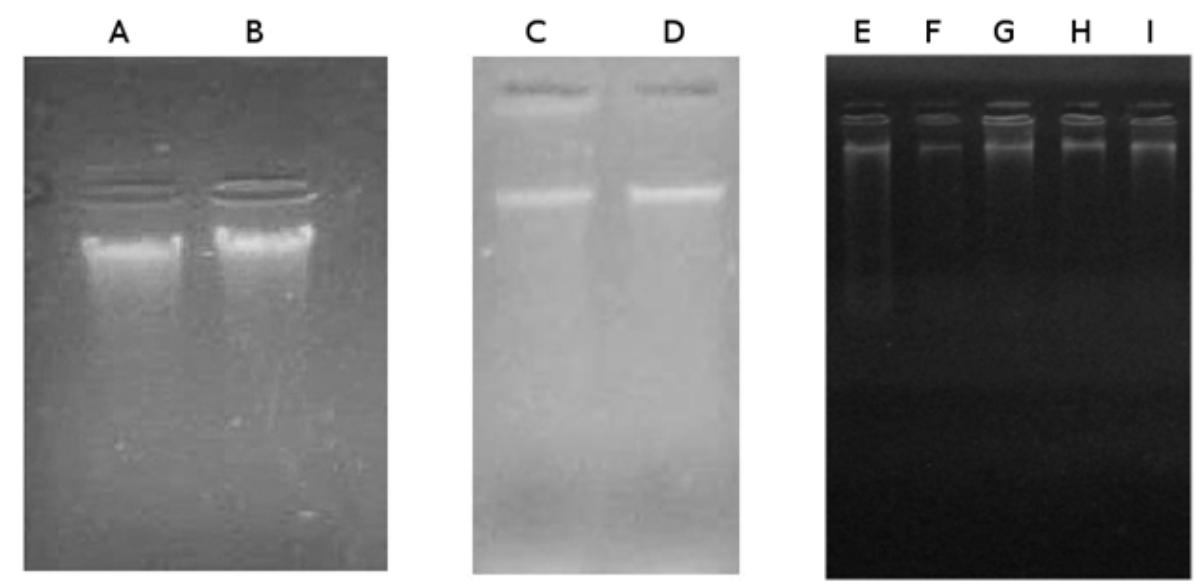

Figure 1. Comparison between two protocols: (A) Drosophila DNA extraction chymosin-based and (B) Drosophila DNA extraction phenol-chloroform; (C) Oryza sativa DNA extraction combined protocols (rennet/glass milk) and (D) Oryza sativa DNA extraction phenol-chloroform; (E) to (I): diverse biological materials; (E) Cicada exuviae with the "rennet/glass milk" protocol; (F) Saintpaulia ionantha with the "rennet/glass milk" protocol; $(\mathrm{G})$ Saccharomyces cerevisae with the "rennet/glass milk" protocol; (H) Escherichia coli with the "rennet/glass milk" protocol; (I) Ipomoea batatas with the "rennet/glass milk" protocol.

Both protocols have low cost and small or no environmental impact and produced satisfactory results in extraction of genomic DNA. We have applied the DNA obtained through these protocols for different purposes, as PCR, Dot and Southern Blot, and to construction of partial genomic libraries.

\section{MATERIALS AND METHODS}

Diverse biological materials have been tested through the developed protocols, including insects of order Diptera (Drosophila), Hemiptera (family Cicadidae) cicada exuviae, yeast (Saccharomyces cerevisae), bacteria (Escherichia coli) and plants (Oryza sativa, Ipomoea batatas, Saintpaulia ionantha).

In the first protocol, which is chymosin-based, a work solution of calf rennet is prepared at $0.25 \mathrm{~g} / \mathrm{ml}$ and maintained at $-20^{\circ} \mathrm{C}$. We normally use the rennet "Coalho em pó HA-LA" (CHR HANSEN IND.COM.LTDA, Valinhos, SP, Brazil) purchased in supermarkets or in farm stores.

Roughly $100 \mathrm{mg}$ of biological material, equivalent to a drop of blood, is homogenized in $600 \mu \mathrm{l}$ of lysis buffer $(0.1 \mathrm{M}$ of Tris/ $\mathrm{HCl} \mathrm{pH} 8,0.1 \mathrm{M}$ of EDTA, $0.06 \mathrm{M}$ of $\mathrm{NaCl}$ ). Usually we perform this homogenization directly in a $1.5 \mathrm{ml}$ microtube using a pistol homogenizer. After homogenization, $60 \mu \mathrm{l}$ of $10 \% \mathrm{SDS}$ is added and the tube is maintained in a water bath at $60^{\circ} \mathrm{C}$ for one hour. After this, $60 \mu \mathrm{l}$ of the rennet work solution is added and the tube is maintained in a water bath at $37^{\circ} \mathrm{C}$ for an additional hour. Following this, $30 \mu \mathrm{l}$ of potassium acetate $(3 \mathrm{M})$ is added, and the tube is maintained for $15 \mathrm{~min}$ in an ice bath $\left(0^{\circ} \mathrm{C}\right)$. Next, $300 \mu$ of chloroform are added to the tube and mixed gently for $10 \mathrm{~min}$. The tube is centrifuged using a benchtop microcentrifuge ( 8.000 to $12.000 \mathrm{rpm}$ ) for $10 \mathrm{~min}$ and the supernatant is transferred to a fresh microtube. The chloroform tube is then discarded into an appropriate container. Two volumes of ethanol are then added to the supernatant, mixed gently, centrifuged for one minute and the pellet is left to dry. The pellet is then resuspended in 50 $\mu \mathrm{l}$ of ultrapure water or TE $(0.01 \mathrm{M}$ Tris/ $\mathrm{HCl}, \mathrm{pH} 8.0 ; 0.05$ M EDTA, pH 8.0).

The second protocol uses glass milk, which is prepared using glass (we normally use broken test tubes). The glass initially is cleaned with hydrogen peroxide (20 volumes), rinsed two times with distillated water and then powdered into fine particles using a mortar and pestle. This procedure, nevertheless, needs some precautions, since the glass powder may be hazardous if breathed or swallowed. Thus, during the glass pulverization protective goggles and

A $\quad$ B

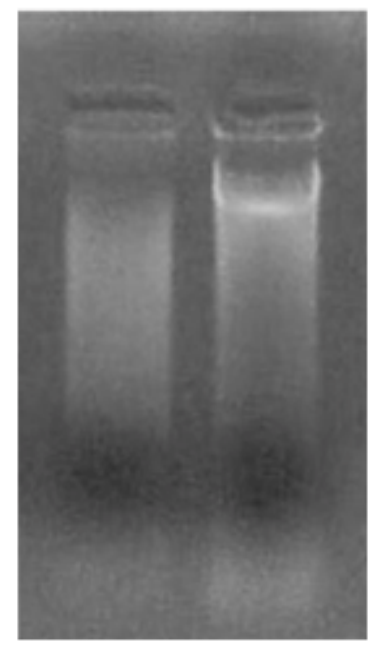

Figure 2. Comparative Hind III digestion profiles exhibited by genomic DNA using Hind III enzymes and DNA obtained with isolated through different protocols. (A) chymosinbased, and (B) phenol-chloroform. 


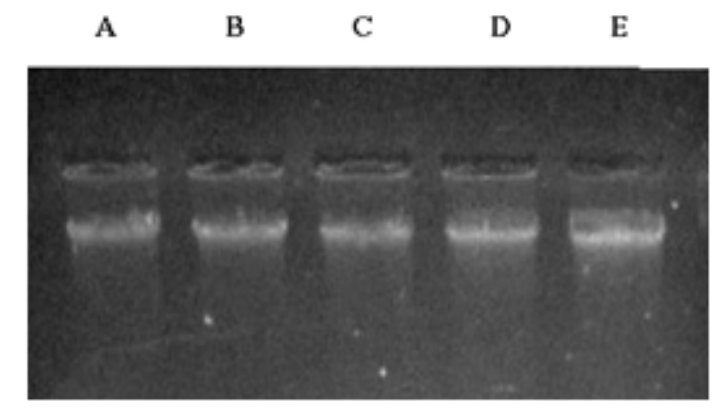

Figure 3. Test of DNA degradation. DNAs were incubated overnight with chymosin (rennet solution) with different final concentrations. (A) $0.071 \mathrm{~g} / \mu \mathrm{l}$; (B) $0.057 \mathrm{~g} / \mu \mathrm{l}$; (C) $0.042 \mathrm{~g} / \mu \mathrm{l}$; (D) $0.023 \mathrm{~g} / \mu \mathrm{l}$; and (E) $0.0 \mathrm{~g} / \mu \mathrm{l}$.

masks must be used. The use of a fume hood is also recommended. After pulverization the glass powder is dissolved in water and decanted over-night. The supernatant is centrifuged and the glass pellet is resuspended in two volumes of distilled water $(\mathrm{pH} \mathrm{2.0)}$ and stored at $-20^{\circ} \mathrm{C}$. Additional details of the glass milk preparation can be obtained at http://www.ufsm.br/labdros/links/glassmilk.pdf.

Next, 20 to $30 \mathrm{mg}$ of biological material are homogenized in $400 \mu \mathrm{l}$ of buffer solution $(0.1 \mathrm{M}$ of Tris/ $\mathrm{HCl}, \mathrm{pH} 8.0 ; 0.1$ $\mathrm{M}$ EDTA, $\mathrm{pH} 8.0 ; 0.06 \mathrm{M} \mathrm{NaCl}$ ) in an $1.5 \mathrm{ml}$ microcentrifuge tube. After homogenization, $50 \mu 1$ of $10 \%$ SDS are added and the tube is maintained in a $60^{\circ} \mathrm{C}$ water bath for one hour. Following this, $50 \mu 1$ of the "rennet work solution" are added to the tube, which is maintained in a $37^{\circ} \mathrm{C}$ water bath for one additional hour, after which $30 \mu \mathrm{l}$ of potassium acetate $(3 \mathrm{M})$ are added. The solution is then mixed gently and maintained for $15 \mathrm{~min}$ in an ice bath. Next, $300 \mu 1$ of chloroform are added and the solution is mixed for $10 \mathrm{~min}$, being then centrifuged for $10 \mathrm{~min}$ in a benchtop microcentrifuge ( 8.000 to $12.000 \mathrm{rpm})$. To the supernatant so obtained, $600 \mu \mathrm{l}$ of $6 \mathrm{M} \mathrm{NaI}$ and $80 \mu \mathrm{l}$ of the glass milk solution are subsequently added. This solution is maintained on the benchtop for $5 \mathrm{~min}$, inverting the tube every $30 \mathrm{sec}$. Next, it is centrifuged for $30 \mathrm{sec}$, the supernatant is removed, and $1 \mathrm{ml}$ of $70 \%$ ethanol is added to completely wash the "glass milk pellet". This last step is repeated two times. Finally, the solution is centrifuged for $30 \mathrm{sec}$, the supernatant is removed, and the pellet is left to dry at room temperature, after which it is resuspended in 20 $\mu \mathrm{l}$ of ultra pure water or TE $(0.01 \mathrm{M}$ Tris $/ \mathrm{HCl}, \mathrm{pH} 8.0 ; 0.05$ M EDTA, $\mathrm{pH}$ 8.0).

For the cleavage of genomic DNA, approximately $3 \mu \mathrm{g}$ were digested over-night at $37^{\circ} \mathrm{C}$ with Hind III restriction endonuclease (Invitrogen) following the manufacturer's instructions. Cleaved DNA was fractioned on a $0.8 \%$ agarose gel and visualized under a UV transiluminator.

To determine whether the rennet solution contained cow DNA, primers specific to the bovine gene IGF-IR (insulin- like growth factor-1 receptor) were used: IGF1-F $=5$ 'ACCCGCCAAGAAATTGTTTC-3' and IGF1-R 5'GGCTCCTCCATACTTCCTGTA-3' (Schoenau et al. 2005). The PCR reactions we performed in a final volume of $25 \mu \mathrm{l}$, using approximately $20 \mathrm{ng}$ of DNA, $0.4 \mu \mathrm{M}$ of each primer, $0.2 \mathrm{mM}$ of each dNTP, $1.5 \mathrm{mM}$ of $\mathrm{MgCl}_{2}$, 1.25 units of Taq DNA polymerase (Invitrogen) and $1 \mathrm{x}$ PCR buffer. After an initial denaturation step of $5 \mathrm{~min}$ at $94^{\circ} \mathrm{C}, 30$ cycles consisting of $1 \mathrm{~min}$ at $94^{\circ} \mathrm{C}, 30 \mathrm{sec}$ at $55^{\circ} \mathrm{C}$ and $1 \mathrm{~min}$ at $72^{\circ} \mathrm{C}$ were carried out, followed by a final extension step of $4 \mathrm{~min}$ at $72^{\circ} \mathrm{C}$.

Additional PCR amplifications were performed to show the efficiency of the chymosin/glass milk-based protocol to obtain DNA pure enough for PCR using specific primers. In this case, the primers used were specific to Tip 100, that correspond to a $h A T$ transposable element from Ipomoea and to the mitochondrial ITS region. The Tip 100 primers sequences were 5'-GCTTCTCAATGGGGCACTTC-3' and 5'-CGTTCTCCTTTTGTTGGTGT-3' (designed by authors), whereas the primers to ITS were 5'AAGGTTTCCGTAGGTGAAC-3' and 5'TATGCTTAAACTCAGCGGG-3' (Desfeux and Lejeune, 1996). The PCR conditions and parameters were the same as above, except that the annealing temperatures corresponded to $50^{\circ} \mathrm{C}$ and $58^{\circ} \mathrm{C}$ for Tip 100 and ITS, respectively.

\section{RESULTS AND DISCUSSION}

The rennet chymosin showed excellent activity as a proteolytic agent for DNA isolation. As can be seen in Figure 1A, the full amount of DNA obtained using this protocol is comparable to those using phenol-chloroform (Sambrook and Russel, 2001). However, it is important to note that rennet is much cheaper than proteinase $\mathrm{K}$ and, in contrast to phenol, has no environmental impact. Digestion assay with restriction enzymes have shown that the DNA obtained is completely digested (Figure 2), being suitable to be further applied in different techniques, including Dot and Southern blotting, PCR and to partial genomic libraries

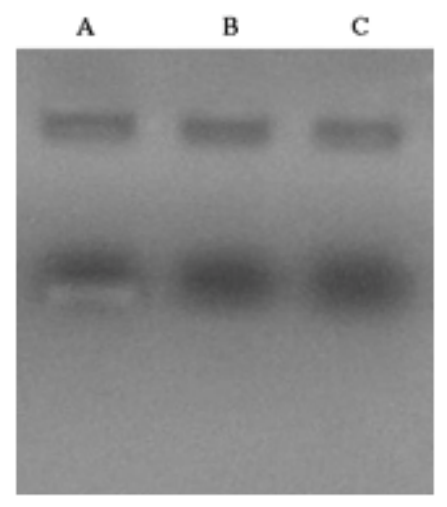

Figure 4. PCR to test the possibility of contamination of rennet with cow DNA. (A) bovine DNA, (B) negative control (without DNA), and (C) Drosophila DNA extracted with the chymosin-based protocol. 
construction (data not shown).

The rennet is a commercial product for domestic or industrial use and not an enzyme isolated for molecular biology purposes. For this reason, the presence of other enzymes as DNAses, or even residual cow DNAs, could jeopardize the use of this product as a proteolytic agent. However, no DNAse activity was detected, since DNA samples exposed overnight to different concentrations of rennet solution did not show any signs of degradation (Figure 3). In addition, contaminant DNA was also not detected. The PCR performed using primers specific to the bovine IGF-IR gene showed no amplification signal in DNA preparations from different biological materials (Figure 4).

Some biological materials, mainly from plants, are sometimes problematic when trying to obtain high quality DNA able to be cleaved or used in PCR amplification. This is due to the presence of secondary metabolites and/or latex in these species. The major components of latex were shown to be conjugates of guaianolide sesquiterpene lactose and lactusin, in others words, polyphenolic conjugates which are produced constitutively as secondary metabolites and phytoalexins. The presence of polyphenolic content makes the isolation of high-quality nucleic acids problematic; in addition, residual polyphenolics interfere in enzymatic reactions such as PCR and endonuclease restriction digestion (Michiels et al. 2003).

We have solved the problem described above for some plants that we have tested, nominally Oriza sativa, Saintpaulia ionantha and many Ipomoea species (Figure $1 \mathrm{~B}$; Figure 1C), by adding to the "rennet DNA extraction protocol" a further step using glass milk. The high affinity of DNA to silica in the presence of a chaotropic salt permits the isolation of high quality DNA, free of polyphenolic contaminants. For the plants mentioned prior, the separate use of only the "rennet extraction DNA protocol" or the described "glass milk protocol" (Boom et al. 1990) does not produce DNA able to be amplified by PCR when using different sets of primers. However, the use of the combined protocol (rennet/glass milk) produced DNA that was capable of being amplified (Figure 5).

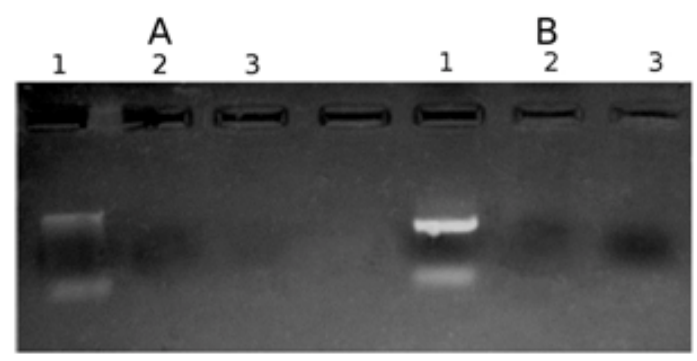

Figure 5. Comparison of PCR results obtained with the use of DNA from Ipomoea purpurea as template, and the Tip 100 (A) or the ITS (B) set of primers. (1) DNA extracted with the protocol rennet/glass milk based; (2) DNA extracted with rennet protocol, and (3) Negative control (without DNA).
Finally, these combined protocols possess the advantage of obtaining DNA from sparse biological materials. For example, we were able to obtain around $1 \mu \mathrm{g}$ of DNA from a single Drosophila fly using this methodology (data not shown). Additionally, the combined protocol was also successfully applied in the extraction of DNA from cicada exuviae (Figure 1E). Feinstein (2004) and $\mathrm{Su}$ et al. (2007) have emphasized that DNA extraction protocol to insect exuviae are important to perform population analyses once do not need collect living wild animal. In fact, the combined use of these protocols increases the possibility of obtaining high quality DNA from diverse biological materials by using safe and inexpensive reagents.

From our knowledge, it is the first description of rennet use as a deproteinization agent for DNA isolation. The major advantage that can be attributed to these protocols refers to costs. The inexpressive price of rennet and the "home made" silica put these protocols among the cheaper ways to obtain DNA with quality to perform PCR, Southern Blot and other procedures. These characteristics make these protocols very useful in laboratories in developing countries, in which the resources to buy commercial kits is, sometimes, sparse. The major problem associated to these protocols is related to time and handwork involved in the glass milk preparation, but this cost is compensated for if a great quantity is made each time and stocked in the freezer $\left(-20^{\circ} \mathrm{C}\right)$. Other characteristic of this protocol is that it is easy and fast to be performed. Usually, in 4-5 work hrs, high quality DNA is isolated and available to be used for many different proposes.

\section{ACKNOWLEDGMENTS}

We are grateful to Dr Lizandra Robe and two anonymous referees for valuable suggestion and to Dr. João F. Oliveira for the cow DNA samples and IGF1-R primers tested here.

\section{REFERENCES}

BACKER, L.E.; MCCORMICK, W.F. and MATTESON, K.J. A silica-based mitochondrial DNA extraction method applied to forensic hair shafts and teeth. Journal of Forensic Sciences, January 2001, vol. 46, no. 1, p. 1-5.

BANSAL, N.; FOX, P.F. and MCSWEENEY, P.L.H. Aggregation of rennet-altered casein micelles at low temperatures. Journal of Agricultural and Food Chemistry, March 2007, vol. 55, no. 8, p. 3120-3126.

BIASE, F.H.; FRANCO, M.M.; GOULART, L.R. and ANTUNES, R.C. Protocol for extraction of genomic DNA from swine solid tissues. Genetics and Molecular Biology, August 2002, vol. 25, no. 3, p. 313-315.

BOOM, R.; SOL, C.J.A.; SALIMANS, M.M.M.; JANSEN, C.L.; WERTHEIM-VAN DILLEN, P.M.E. and NOORDAA, J.V.D. Rapid and simple method for purification of nucleic acids. Journal of Clinical Microbiology, March 1990, vol. 28, no. 3, p. 495-503. 
CHAN, P.K.S.; CHAN, D.P.C.; MYYU, K-T.T.; CHEUNG, J.L.K. and CHENG, A.F. Evaluation of extraction methods from paraffin wax embedded tissues for PCR amplification of human and viral DNA. Journal of Clinical Pathology, September 2001, vol. 54, no. 5, p. 401403.

CHOI, J.; HORNE, D.S. and LUCEY, J.A. Effect of insoluble calcium concentration on rennet coagulation properties of milk. Journal Dairy Science, January 2007, vol. 90 , no. 6, p. 2612-2623.

DESFEUX, C. and LEJEUNE, B. Systematics of Euromediterranean Silene (Caryophyllaceae): evidence from a phylogenetic analysis using ITS sequences. Comptes Rendus de l'Academie des Sciences de Paris, April 1996, vol. 319 , no. 4, p. 351-358.

ENGLAND, L.S.; TREVORS, J.T. and HOLMES, S.B. Extraction and detection of baculoviral DNA from lake water, detritus and forest litter. Journal of Applied Microbiology, January 2001, vol. 90, no. 4, p. 630-636.

FEINSTEIN, Julie. DNA sequence from butterfly frass and exuviae. Conservation Genetics, January 2004, vol. 5, no. 1, p. 103-104.

GRACHEV, M.A.; KUZNETSOVA, S.Y. and SHERBAKOVA, T.A. A method for the isolation of pure DNA for PCR. Molecular Biology, January 2006, vol. 40, no. 1, p. $159-161$.

HAUGLAND, Richard A.; HECKMAN, John L. and WYMER, Larry J. Evaluation of different methods for the extraction of DNA from fungal conidia by quantitative competitive PCR analysis. Journal of Microbiological Methods, April 1999, vol. 37, no. 2, p. 165-176.

HAUGLAND, Richard A.; BRINKMAN, Nichole and VESPER, Stephen J. Evaluation of rapid DNA extraction methods for the quantitative detection of fungi using realtime PCR analysis. Journal of Microbiological Methods, February 2002, vol. 50, no. 39, p. 319-323.

HUIJUN, T.; HÜHMER, A.F.R. and LANDERS, J.P. Evaluation of silica resins for direct and efficient extraction of DNA from complex biological matrices in a miniaturized format. Analytical Biochemistry, August 2000, vol. 283, no. 2, p. 175-191.

MELZAK, Kathryn A.; SHERWOOD, Chris S.; TURNER, Robin F.B. and HAYNES, Charles A. Driving forces for DNA adsorption to silica in perchlorate solution. Journal of Colloid and Interface Science, August 1996, vol. 181, no. 2, p. 635-644.

MICHIELS, An; VAN DEN ENDE, Wim; TUCKER, Mark; VAN RIET, Liesbet and VAN LAERE, André. Extraction of high-quality genomic DNA from latex- containing plants. Analytical Biochemistry, March 2003, vol. 315 , no. 1 , p. 85-89.

MOHANTY, Ashok K.; MUKHOPADHYAY, Utpal K.; KAUSHIK Jai K.; GROVER, Sunita and BATISH, Virender K. Isolation, purification and characterization of chymosin from riverine buffalo (Bubalos bubalis). Journal of Dairy Research, February 2003, vol. 70, no. 1, p. 37-43.

NAKAMA, A. and MORISHITA, F. Examination of DNA extract from kernels and processed foods using silica-base resin. Journal of the Food Hygienic Society of Japan, August 2004, vol. 45, no. 4, p. 207-211.

NIEMI, Maarit R.; HEISKANEN, Ilse; WALLENIUS, Kaisa and LINDSTRÖM, Kristina. Extraction and purification of DNA in rhizosphere soil samples for PCRDGGE analysis of bacterial consortia. Journal of Microbiological Methods, July 2001, vol. 45, no. 3, p. 155165.

RAMPILLI, Marco; LARSEN, Raul and HARBOE, Marianne. Natural heterogeneity of chymosin and pepsin in extracts of bovine stomachs. International Dairy Journal, March 2005, vol. 15, no. 11, p. 1130-1137.

ROHLAND, Nadin; SIEDEL, Heike and HOFREITER, Michael. Nondestructive DNA extraction method for mitochondrial DNA analyses of museum specimens. BioTechniques, May 2004, vol. 36, no. 5, p. 814-821.

ROS-CHUMILLAS, Maria; EGEA-CORTINES, Marcos; LOPEZ-GOMES, Antonio and WEISS, Julia. Evaluation of a rapid DNA extraction method to detect yeast cells by PCR in orange juice. Food Control, January 2007, vol. 18, no. 1, p. 33-39.

SAMBROOK, J. and RUSSEL, D.W. Molecular cloning: $a$ laboratory manual. 3ed. New York; Cold Spring Harbor Laboratory Press, 2001. 2344 p. ISBN 0-87969-577-3.

SANDRA, S.; ALEXANDER, M. and DALGLEISH, D.G. The rennet coagulation mechanism of skim milk as observed by transmission diffusing wave spectroscopy. Journal of Colloid and Interface Science, January 2007, vol. 308, no. 2, p. 364-373.

SATO, Yuichi; SUGIE, Rikako; TSUCHIYA, Benio; KAMEYA, Toru; NATORI, Michiya and MUKAI, Kiyoshi. Comparison of the DNA extraction methods for polymerase chain reaction amplification from formalinfixed and paraffin-embedded tissues. Diagnostic Molecular Pathology, December 2001, vol. 10, no. 4, p. 265-271.

SCHOENAU, W.; PORCIUNCULA, P.M.; ZAMBERLAN, G.; MESQUITA, F.S.; VIEIRA, V.; OLIVEIRA, J.F.C. and GONÇALVES, P.B.D. Association between IGF-IR gene polymorphisms and productive and reproductive traits in Holstein cows. Arquivo Brasileiro de 
Valter de Oliveira, L.F. et al.

Medicina Veterinaria e Zootecnia, January 2005, vol. 57, no. 6, p. 772-776.

SU, Songkun; ALBERT, Stefan; ZHANG, Shaowu; MAIER, Sven; CHEN, Shenglu; DU, Honghu and TAUTZ, Jürgen. Non-destructive genotyping and genetic variation of Fanning in a honey bee colony. Journal of Insect Physiology, May 2007, vol. 53, no. 5, p. 411-417.

The UniProt Consortium. The Universal Protein Resource (UniProt). Nucleic Acids Research, 2008, vol. 36, Database issue, p. D190-D195.

ZHANG, D.; CHEN, Y.; CHEN, H.-Y. and XIA, H. Silicananoparticle-based interface for the enhanced immobilization and sequence-specific detection of DNA. Analytical and Bioanalytical Chemistry, June 2004, vol. 379, no. 7-8, p. 1025-1030. 